\title{
PRAGMATISME, HUMANISME DAN IMPLIKASINYA BAGI DUNIA PENDIDIKAN DI INDONESIA
}

\author{
Wasitohadi \\ Staf pengajar Progdi PPKn FKIP-Universitas Kristen Satya Wacana
}

\begin{abstract}
ABSTRAK
Praksis implementasi pendidikan mestinya mengacu pada teori pendidikan dan didasarkan pada landasan filosofis yang jelas. Agar praksis pendidikan tersebut dibimbing oleh teori (action guided by theories), maka pemahaman terhadap teori pendidikan dan akar filosofisnya menjadi penting dan strategis.

Salah satu aliran filsafat yang pengaruhnya besar terhadap dunia pendidikan adalah pragmatisme. Pragmatisme meyakini bahwa benar tidaknya suatu teori bergantung pada berfaedah tidaknya teori itu bagi manusia dalam penghidupannya. Dengan demikian, ukuran untuk segala perbuatan adalah manfaatnya dalam praktek dan hasil yang memajukan hidup.

Kaitan antara filsafat pragmatisme dengan humanisme, dapat dipahami dengan melihat pengaruh pragmatisme terhadap pendidikan modern melalui pengaruh teori pendidikan progressivisme. Humanisme pendidikan mengadopsi sebagian besar dari prinsip-prinsip progressivisme, yaitu keterpusatan pada anak, peran guru yang tidak otoritatif, pemfokusan pada subyek didik yang terlibat aktif dan tekanannya pada sisi pendidikan kooperatif dan demokratis.

Implikasi pragmatisme bagi dunia pendidikan di Indonesia, antara lain tercermin dari adanya penghormatan dan penerapan terhadap prinsip-prinsip pendidikan berbasis pengalaman dan pendidikan yang berpusat pada subyek didik.
\end{abstract}

Kata kunci : Pragmatisme, Humanisme, Pendidikan Berbasis Pengalaman, Pendidikan berpusat pada subyek didik.

\section{PENDAHULUAN}

Keprihatinan mengenai lepasnya praksis pendidikan dari pijakannya, yakni filsafat pendidikan, telah berlangsung lama. Winarno Surakhmad (2005) dalam makalahnya berjudul "Mendidik Memang Tidak Memerlukan Ilmu Pendidikan", misalnya, menyatakan dan merisaukan bahwa yang sekarang berkembang di Indonesia adalah praktek pendidikan tanpa ilmu pendidikan (PENTIP), sejalan dengan hasrat manusia untuk menjadi semakin praktis dan pragmatis, bahkan 'machiavellian'. Kompas beberapa tahun lalu, juga memuat tulisan bernada keprihatinan atas "Matinya Filsafat Pendidikan" (Kompas, 10 Maret 2007) dan "Mandeknya Pemikiran Pendidikan" (Kompas, 18 Januari 2007) di Indonesia. Padahal, mestinya, praktek implementasi pendidikan mengacu kepada ilmu pendidikan, dan didasarkan pada landasan filosofis yang jelas.

Dalam tulisan ini, penulis akan membahas mengenai "Pragmatisme, Humanisme, dan Implikasinya Bagi Dunia Pendidikan di Indonesia". Pembahasan mencakup filsafat pragmatisme, arti dan ciri-cirinya, serta kaitan sekaligus pengaruh pragmatisme terhadap humanisme pendidikan ${ }^{1}$. Juga akan dibahas pandangan pragmatisme tentang pendidikan, terutama menyangkut komponenkomponen yang esensial. Sesudah itu, akan dibahas mengenai implikasi pandangan pragmatisme bagi dunia pendidikan di Indonesia, baik implikasi teoritis maupun praktis. Pada sisi praktis, akan

${ }^{1}$ Uraian dalam bagian ini menggunakan sumber utama dari buku: George R. Knight. (1982). Issues and Alternatives in educational Philosophy. Michigan: Andrews University Press. Tambahan dari sumber lain, sebagian langsung dimasukkan dalam tulisan, sedangkan sebagian lainnya ditempatkan pada footnote di bawah masing-masing halaman. 
diberikan contoh ${ }^{2}$ penerapan konsep "pendidikan yang berbasis pengalaman", dalam pembelajaran berdasarkan kurikulum KTSP. Contoh ini diberikan terbatas pada matapelajaran "Pendidikan Kewarganegaraan" SMA, meskipun sebenarnya dapat diterapkan pula pada matapelajaran lain di semua jenjang pendidikan. Kemudian, akan dilanjutkan dengan kesimpulan sebagai penutup makalah ini.

\section{FILSAFAT PRAGMATISME}

Secara etimologis, kata pragmatisme berasal dari bahasa Yunani "pragma", adapula yang menyebut dengan istilah "pragmatikos", yang berarti tindakan atau aksi. Pragmatisme berarti filsafat atau pemikiran tentang tindakan (Keraf,1987:15). Filsafat ini menyatakan bahwa benar tidaknya suatu teori bergantung pada berfaedah tidaknya teori itu bagi manusia dalam penghidupannya. Dengan demikian, ukuran untuk segala perbuatan adalah manfaatnya dalam praktek dan hasil yang memajukan hidup. Benar tidaknya sesuatu hasil pikir, dalil maupun teori, dinilai menurut manfaatnya dalam kehidupan atau menurut berfaedah tidaknya teori itu dalam kehidupan manusia. Atas dasar itu, tujuan kita berfikir adalah memperoleh hasil akhir yang dapat membawa hidup kita lebih maju dan lebih berguna. Sesuatu yang menghambat hidup kita adalah tidak benar.

Aliran filsafat ini mencuat ke permukaan selama seratus tahun terakhir dan dikaitkan dengan nama-nama berikut: Charles Sanders Peirce (1839-1914), William James (1842-1910) dan John Dewey (1859-1952). ${ }^{3}$ Filsafat-filsafat tradisional bersifat statis dan cenderung melihat segala sesuatu sebagaimana adanya. Pada paruh terakhir abad XIX terlihat adanya perubahan yang tak terduga setelah revolusi industri meluncur dengan cepat. Industrialisasi, urbanisasi, dan migrasi penduduk secara besar-besaran merupakan faktor sentral dalam alam kehidupan bangsa Amerika. Perubahan menjadi ciri sentral dari eksistensi manusia. Dalam kancah intelektual, teori biologis sosial Darwinisme telah berkembang dan secara luas diakui sebagai pengetahuan umum masyarakat untuk merasionalkan dan menyetujui tentang konsep perubahan. Pragmatisme (sering juga disebut eksperimentalisme dan instrumentalisme) adalah reaksi filosofis terhadap fenomena ini. ${ }^{4}$

William James merumuskan pragmatisme sebagai "sikap memalingkan muka dari segala sesuatu, prinsip-prinsip, kategori-kategori, keniscayaan-keniscayaan awal, untuk kemudian beralih pada segala sesuatu, hasil-hasil, konsekuensi-konsekuensi, serta fakta-fakta baru." Pragmatisme bersifat kritis terhadap sistem-sistem filsafat lama, yang menurut penganut pragmatisme, telah membuat kesalahan mencari sesuatu yang puncak (ultimate), mutlak, dan esensi-esensi abadi. Para penganut pragmatisme menekankan sains empiris, dunia yang berubah dan masalah-masalahnya, dan alam sebagai seluruh realitas inklusif di luar keyakinan ilmiah tidak mendapat tempat.

\footnotetext{
${ }^{2}$ Contoh ini penulis anggap penting, karena filsafat pendidikan pada intinya adalah filsafat yang diterapkan dalam usaha pemikiran dan pemecahan mengenai masalah pendidikan (Imam Barnadib, 1997: 7). Pilihan pada konsep "pendidikan berbasis pengalaman" didasarkan pada fakta bahwa salah satu ciri dari filsafat pragmatisme adalah tekanan dan perhatiannya pada pentingnya pengalaman inderawi manusia. Oleh karena itu, sebagaimana ditegaskan dan dikembangkan oleh salah satu tokoh pragmatisme John Dewey, pendidikan harus berbasis pada pengalaman.

${ }^{3}$ Charles Peirce sering disebut sebagai "penemu" (perintis, yang memperkenalkan) pragmatisme, sedangkan William James sering dipandang sebagai bapak pragmatisme, yang memformulasikan pragmatisme, sedangkan John Dewey adalah tokoh pragmatisme modern, yang menyebarluaskan atau memasyarakatkan pragmatisme (Albertine Minderop, 2005: 95).

${ }^{4}$ Bandingkan dengan pendapat Albertine Minderop (2005:5,12) yang menyatakan bahwa latarbelakang lahirnya pragmatisme diawali dengan adanya perdebatan antara realisme dengan idealisme dan empirisme dengan rasionalisme. Perdebatan ini pada dasarnya dilandasi oleh pemikiran, bagaimana fungsi atau peran filsafat dalam kehidupan manusia. Menurut para tokoh pragmatisme, filsafat yang ada selama ini belum mampu memberikan jawaban yang memuaskan terhadap kehidupan manusia. Oleh karena itulah, mereka menawarkan sesuatu yang praktis bagi kehidupan manusia, yang beorientasi pada asas efisiensi dan manfaat. Untuk itulah, muncul pragmatisme.
} 
Pragmatisme mempunyai pijakan intelektual dalam pemikir-pemikir Yunani, seperti Heracleitos (abad V SM) yang mempostulatkan keniscayaan perubahan ${ }^{5}$ dan para penganut empirisme Inggris ${ }^{6}$ (abad XVII dan XVIII) yang menandaskan bahwa orang hanya dapat mengetahui apa yang dialami indera mereka.

Pragmatisme memiliki tiga ciri, yaitu: (1) memusatkan perhatian pada hal-hal dalam jangkauan pengalaman indera manusia, (2) apa yang dipandang benar adalah apa yang berguna atau berfungsi, dan (3) manusia bertanggung jawab atas nilai-nilai dalam masyarakat (George R. Knight, 1982). Pertama, dari perspektif penganut pragmatisme, kita hidup dalam sebuah dunia pengalaman. Dalam perjalanan waktu, pengalaman manusia tersebut berubah dan karenanya konsep pragmatisme tentang kenyataanpun juga berubah. Di luar pengalaman manusia, tak ada kebenaran atau kenyataan yang sesungguhnya. Dengan demikian, penganut pragmatisme menolak pemikiran metafisika. Bagi mereka, tidak ada hal yang absolut, tidak ada prinsip apriori atau hukum alam yang tidak berubah. Kenyataan bukanlah sesuatu yang abstrak, ia lebih sebagai sebuah pengalaman transaksional yang terus-menerus berubah. Apa yang "nyata" di hari ini dapat "tidak nyata" di hari esok, sebab kenyataan tidak dapat dipisahkan dari pengalaman. Kita hidup dalam dunia yang dinamis, yang selalu berubah dan ada hukum-hukum ilmiah yang didasarkan pada pengalaman manusia yang terbatas, yang harus dipandang sebagai probabilitas, bukan yang absolut. Menurut kaum pragmatis, pikiran dan materi bukanlah dua hal yang terpisah dan substansi yang independen. Orang hanya mengetahui tentang materi sebagaimana mereka mengalaminya dan merefleksikan pengalaman ini dengan pikirannya. Oleh karena itu kenyataan tidak pernah terpisah dari manusia yang mengetahui.

Kedua, pragmatisme pada dasarnya adalah sebuah pemikiran epistemologis. Pengetahuan, menurut kaum pragmatis, berakar pada pengalaman. Manusia mempunyai pemikiran yang aktif dan eksploratif, bukan pasif dan reseptif. Manusia tidak hanya menerima pengetahuan, ia juga membuat pengetahuan itu sebagai hasil interaksinya dengan lingkungan. Jadi, usaha pencarian pengetahuan adalah sebuah transaksi. Manusia berbuat terhadap lingkungannya, kemudian ia mengalami konsekuensi-konsekuensi tertentu. Ia belajar dari pengalaman transaksionalnya dengan dunia di sekelilingnya.

Selain itu, pengetahuan dari perspektif pragmatis perlu dibedakan dari keyakinan atau kepercayaan. Hal-hal autentik tentang keyakinan manusia adalah urusan pribadi, tetapi apa yang ia anggap perlu diketahui harus dapat didemonstrasikan kepada pengamat yang memenuhi syarat dan tak berpihak. Dengan kata lain, kepercayaan (keimanan) itu bersifat pribadi, sedangkan pengetahuan adalah hal yang senantiasa bersifat publik. Dari sudut pandang pragmatis, sebuah pernyataan dikatakan benar adalah jika dapat diuji dengan pengalaman empiris yang bersifat publik. Selain itu, posisi epistemologi kaum pragmatis tidak memberi tempat pada konsep-konsep apriori dan kebenaran-kebenaran absolut. Manusia hidup dalam dunia pengalaman yang berubah secara terusmenerus dan "apa yang berguna dan berfungsi" di hari ini bisa terbukti sebagai sebuah penjelasan

\footnotetext{
${ }^{5}$ Herakleitos beranggapan bahwa dalam dunia alamiah tidak ada sesuatupun yang tetap. Tidak ada sesuatupun yang dianggap definitif atau sempurna. Segala sesuatu yang ada senantiasa "sedang menjadi'. Terkenallah ucapannya panta rhei, artinya : semuanya mengalir. Sebagaimana air sungai senantiasa mengalir terus, demikianpun dalam dunia jasmani tidak ada sesuatupun yang tetap. Semuanya berubah terus menerus.

${ }^{6}$ Istilah empirisme berasal dari kata Yunani empeiria yang berarti "pengalaman inderawi'. Empirisme memilih pengalaman sebagai sumber utama pengenalan dan yang dimaksudkan dengannya adalah baik pengalaman lahiriah yang menyangkut dunia maupun pengalaman batiniah yang menyangkut pribadi manusia saja. Tidak mengherankan bila rasionalisme dan empirisme masing-masing mempunyai pendirian yang sangat berlainan tentang sifat pengenalan manusiawi. Rasionalisme mengatakan bahwa pengenalan yang sejati berasal dari rasio, sehingga pengenalan inderawi merupakan suatu bentuk pengenalan yang kabur saja. Sebaliknya, empirisme berpendapat bahwa pengetahuan berasal dari pengalaman, sehingga pengenalan inderawi merupakan bentuk pengenalan yang paling jelas dan sempurna.
} 
yang tidak memadai lagi di esok hari. Oleh karena itu, kebenaran bersifat relatif dan apa yang benar di hari ini bisa tidak benar di waktu mendatang atau dalam konteks situasi yang berbeda.

Ketiga, manusia bertanggung jawab atas nilai-nilai dari masyarakat. Nilai-nilai bersifat relatif dan tidak ada prinsip-prinsip absolut yang dapat dipedomani. Sebagaimana budaya berubah, demikian juga nilai-nilaipun berubah. Ini tidak berarti bahwa moralitas tidak mengalami pasang surut dari hari ke hari, akan tetapi ini berarti bahwa tidak ada aturan aksiologis yang dapat dianggap sebagai hal yang mengikat secara universal. Menurut kaum pragmatis, apa yang secara etis baik adalah apa yang berguna dan berfungsi. Dengan demikian, seperti halnya pengujian epistemologis itu bersifat publik, maka pengujian etis itu juga didasarkan pada hal yang baik menurut kriteria sosial kemasyarakatan dan bukan semata-mata didasarkan pada landasan personal yang bersifat pribadi.

George R. Knight (1982) memberi ilustrasi contoh sebagai berikut.

....jika tujuanku adalah untuk meraih kekayaan, maka aku mungkin beranggapan bahwa akan tercapai tujuanku jika aku menjadi seorang pencuri. Dengan cara ini, secara pribadi aku akan mencapai suatu tingkat kekayaan tertentu. Karena hasil yang diraih adalah kepuasan, dalam arti sesuatu yang telah menjadikanku kaya, aku mungkin tergiur untuk beranggapan bahwa hal ini bermoral. Namun, menurut penganut pragmatisme, ketika hal itu mungkin berguna dan berfungsi bagi seseorang, ia jelas tidak mungkin berguna dan berfungsi bagi sistem sosial secara utuh karena tak seorangpun akan mampu mengumpulkan kekayaan jika setiap orang yang lainnya berbuat mencuri. Dengan demikian, ketika diletakkan pada pengujian publik, tindakan mencuri gagal menjadi berguna dan tidak bisa dirumuskan sebagai hal baik atau bermoral karena ia akan membuat kehidupan yang berkeadaban menjadi tidak mungkin terwujud....

\section{PRAGMATISME DAN HUMANISME PENDIDIKAN}

Kaitan sekaligus pengaruh pragmatisme dengan humanisme pendidikan dapat dilihat dalam bagan berikut (George R. Knight, 1982:79).

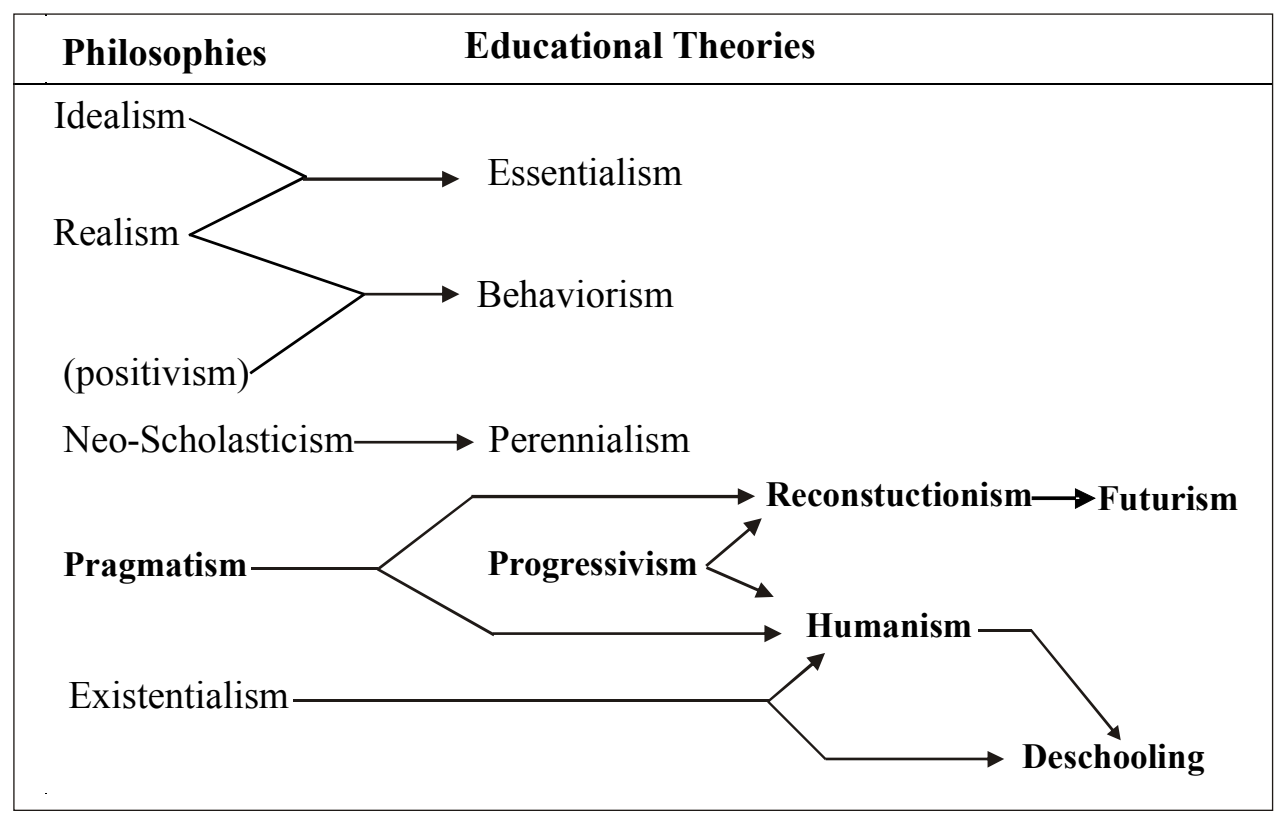

Dari bagan di atas, tampak bahwa kaitan sekaligus pengaruh filsafat pragmatisme terhadap humanisme pendidikan modern terwujud melalui pengaruh teori pendidikan progresivisme. 
Pragmatisme juga mempengaruhi pendidikan baik secara langsung maupun tidak, melalui rekonstruksionisme, futurisme, dan deschooling dalam pendidikan. ${ }^{7}$

Progresivisme berakar pada pragmatisme. ${ }^{8}$ Progresivisme melihat peserta didik sebagai makhluk yang aktif dan kreatif. Kreativitas tersebut hanya dapat diperoleh melalui pengalaman. Sebagai makhluk sosial, proses belajar peserta didik akan lebih berhasil di dalam ikatan dengan kelompok. Dalam hal ini, guru lebih sebagai fasilitator dalam proses belajar dan pendidikan mempunyai multi fungsi untuk pengembangan fisik, emosional, sosial dan intelektual anak. Menurut H.A.R Tilaar (2005:314), aliran progresivisme di dalam pendidikan memunculkan aliran rekonstruksionisme yang melihat pendidikan sebagai agen perubahan sosial, politik dan ekonomi.

Selain itu, progresivisme juga percaya kepada kemajuan masyarakat melalui langkah-langkah yang tersusun, ke arah masa depan (futurisme) namun bukan suatu utopia masa depan. Progresivisme didasarkan kepada paham liberalisme, yaitu kepercayaan kepada prosedur publik dan bukan kepada hal-hal yang tidak transparan. Oleh sebab itu, progresivisme menekankan kepada pentingnya menumbuhkan konsensus atau kesepakatan-kesepakatan. Pendidikan merupakan suatu sarana di dalam membangun suatu konsensus dalam mana masyarakat mempelajari prosedur serta praktis dari komitmen bersama.

Pendidikan progresif berdasarkan tiga agenda, yaitu (1) meninggalkan berbagai jenis formalisme, rutinitas, dan birokrasi yang menghantui cara belajar di sekolah;(2) mempraktekkan metode inovatif yang difokuskan kepada minat serta kebutuhan peserta didik; dan (3) profesionalisasi mengajar serta administrasi sekolah. Pendidikan progresif menekankan pada "learning by doing", belajar melalui pengalaman, belajar aktif, belajar secara kelompok serta problem solving. ${ }^{9}$

Beberapa ide gagasan progresive telah diperbaharui dalam humanisme pendidikan akhir dekade 1960-an dan awal 1970-an. Kaitan progresivisme dengan humanisme pendidikan secara rinci sebagai berikut.

1. Humanisme pendidikan mengadopsi sebagian besar dari prinsip-prinsip progresivisme, yaitu keterpusatan pada anak, peran guru yang tidak otoritatif, pemfokusan pada subyek didik yang terlibat aktif dan tekanan pada sisi pendidikan kooperatif dan demokratis.

2. Progresivisme bukanlah satu-satunya sumber humanisme pendidikan. Sumber lainnya adalah eksistensialisme (yang memberikan tekanan pada keunikan anak secara perorangan daripada yang telah diberikan oleh kalangan progresive (yang cenderung lebih memahami anak dalam kaca mata unit sosial saja). Oleh karena itu, pencarian makna personal atau pemusatan pada anak secara perorangan menjadi penting. Sumber lainnya adalah kalangan psikolog eksistensial/ humanistik, seperti Carl Rogers, Abraham Maslow dan Arthur Combs. Tekanannya pada perlunya pemberian bantuan pada subyek didik agar dapat menjadi "terhumanisasikan" atau "teraktualisasi diri"- membantu subyek didik secara perorangan dalam menemukan, menjadi dan mengembangkan kedirian sejatinya serta keutuhan potensinya. Sumber lainnya adalah kritikus-kritikus romantik (yang muncul sebagai protes terhadap keadaan-keadaan sekolah

\footnotetext{
7 Adalah menarik dan sangat penting untuk memahami berbagai konsep tersebut secara detail, namun dalam makalah ini cukuplah kiranya untuk menjelaskan "sekedar pengertian singkat" berbagai konsep tersebut.

8 Selain pada pragmatisme, progresivisme juga berakar pada teori psikoanalisis Freud (yang menekankan pada pemberian kebebasan yang lebih bagi ekspresi diri di antara anak-anak dan suatu lingkungan pembelajaran yang lebih terbuka di mana anak-anak dapat melepaskan energi dorongan-dorongan instinktif mereka dalam cara-cara yang kreatif), dan karya Emile oleh Rousseau ( yang cenderung menentang terhadap adanya campur tangan orang-orang dewasa dalam menetapkan tujuan-tujuan pembelajaran atau kurikulum subyek didik (George R. Knight,1982:80-81)

9 Bandingkan dengan George R. Knight (1982:82-86).
} 
yang represif, tidak manusiawi, dan tidak nalar. Mereka menandaskan bahwa sekolah-sekolah menjadi mematikan secara intelektual dan destruktif secara psikologis karena mereka lebih disibukkan dengan aturan dan hukuman daripada kesehatan dan perkembangan manusia. ${ }^{10}$

Sementara itu, perlu ditambahkan bahwa menurut Albertine Minderop (2005: 120), pragmatisme menjadi (disebut) humanisme karena keyakinan bahwa nasib manusia berada di tangan sendiri, bukan dari kekuatan lain. Jadi, manusia selalu memiliki kemampuan menjadi kuat, sehingga manusia tidak perlu menyesuaikan diri dengan alam, melainkan alam yang mengikuti kehendak manusia. Dengan demikian, manusia bukan lagi manusia biasa melainkan manusia super-superman.

Pada sisi lain, dengan kesadaran bahwa nasib manusia berada di tangan sendiri, ini menjadi dasar untuk melakukan "pilihan bebas mandiri" mengenai corak pendidikan macam apa yang semestinya diberikan kepada anak. Pada situasi di mana orang tua tidak puas lagi dengan kinerja pendidikan formal, hal itu akan mudah menumbuhkan berkembangnya deschooling dalam pendidikan, termasuk berbagai pendidikan alternatif lainnya.

Uraian berikut memuat berbagai pandangan filsafat pragmatisme terhadap berbagai komponen esensial dalam pendidikan.

\section{a. Pengalaman sebagai Basis Pendidikan}

Salah satu kata kunci dalam filsafat pragmatisme, terutama yang dikembangkan John Dewey, adalah "pengalaman" (experience) ${ }^{11}$. Apa yang ia maksudkan dengan pengalaman? Pengalaman adalah keseluruhan kegiatan dan hasil yang kompleks serta bersegi banyak dari interaksi aktif manusia, sebagai makhluk hidup yang sadar dan bertumbuh, dengan lingkungan di sekitarnya yang terus berubah dalam perjalanan sejarah (Sudarminta, 2004). Melawan berbagai bentuk dualisme, bagi Dewey, pengalaman selalu memuat kutub subyek (dengan segala keinginan, kepentingan, perasaan, sejarah, budaya, dan latar belakang pengetahuannya) maupun obyek (dengan segala kompleksitasnya), mental maupun fisik, rasional maupun empirik. Pengertian ini dikemukakan oleh Dewey sebagai reaksi terhadap dua bentuk pereduksian atau pemiskinan pengertian pengalaman yang pada waktu itu umum dilakukan.

Pertama, dilakukan oleh kaum empiris Inggris yang bersifat atomistik dan memahami pengalaman hanyalah sebagai data inderawi yang dapat diserap oleh manusia (khususnya melalui indra penglihatan dan pendengarannya) dan lingkungan sekitarnya. Kaum empiris, mereduksi pengalaman pada kutub obyek yang dialami. Sebagai akibatnya, menurut Dewey, empirisme mereka menjadi tidak cukup radikal, karena menghilangkan segi-segi pengalaman empiris pada kutub subyek yang mengalami.

Kedua, dilakukan oleh kaum rasionalis yang cenderung melecehkan pengalaman sebagai hal yang tidak pasti kebenarannya dan mudah mengecoh. Di mata Dewey, kaum rasionalis melakukan apa yang ia sebut "the fallacy of intellectualism". Yang ia maksudkan, kaum rasionalis terlalu mendewakan pengetahuan intelektual, sehingga memandang tindakan mengalami melulu sebagai sebuah cara mengetahui (a made of knowing). Pengalaman tidak lain hanyalah suatu bentuk primitif pengetahuan. Bagi Dewey, pengalaman jauh lebih kaya dan kompleks dibandingkan dengan pengetahuan. Ia melawan dominasi epistemologi dalam filsafat modern. Realitas pertama-tama adalah realitas untuk dialami dan bukan untuk diketahui. Kegiatan mengetahui tidak dapat dilepaskan dari konteks kehidupan tempat kegiatan tersebut dilakukan.

\footnotetext{
${ }^{10}$ Selanjutnya, prinsip-prinsip humanistic, silakan lihat George R. Knight (1982:87-88).

${ }^{11} \mathrm{Hal}$ ini misalnya terungkap dari kenyataan bahwa bukan hanya tiga dari buku-buku yang ditulisnya memakai judul yang memuat kata pengalaman, tetapi juga bahwa dalam hampir semua bukunya, konsep dasar itu kembali muncul.
} 
Menurut Dewey, pengalaman adalah basis pendidikan, atau dalam terminologi Dewey sendiri "pengalaman" sebagai "sarana dan tujuan pendidikan”.(John Dewey, 2004:ix). Oleh karena itu, bagi John Dewey, pendidikan pada hakekatnya merupakan suatu proses penggalian dan pengolahan pengalaman secara terus-menerus. Inti pendidikan tidak terletak dalam usaha menyesuaikan dengan standar kebaikan, kebenaran dan keindahan yang abadi, melainkan dalam usaha untuk terus-menerus menyusun kembali (reconstruction) dan menata ulang (reorganization) pengalaman hidup subjek didik. Seperti dirumuskan oleh John Dewey sendiri dalam bukunya, bahwa perumusan teknis tentang pendidikan, yakni "menyusun kembali dan menata ulang pengalaman yang menambahkan arti pada pengalaman tersebut, dan yang menambah kemampuan untuk mengarahkan jalan bagi pengalaman berikutnya". Dengan kata lain, pendidikan haruslah memampukan subjek didik untuk menafsirkan dan memaknai rangkaian pengalamannya sedemikian rupa, sehingga ia terus bertumbuh dan diperkaya oleh pengalaman tersebut.

Demikianlah, bagi Dewey, pertumbuhan subyek didik melalui penyusunan kembali dan penataan ulang pengalaman menjadi hakikat sekaligus tujuan pendidikan. Namun, kendati pendidikan yang sejati dalam keyakinan Dewey selalu diperoleh melalui pengalaman, namun ia juga menyadari bahwa tidak semua pengalaman bersifat mendidik. Ada pula pengalaman yang bersifat tak mendidik, yakni pengalaman yang berakibat menghentikan dan merusak pertumbuhan ke arah peningkatan kualitas pengalaman selanjutnya yang lebih kaya. Baginya, masalah pokok pendidikan yang berbasiskan pengalaman adalah memilih jenis pendidikan berdasarkan pengalaman yang dapat tetap hidup subur dan kreatif dalam pengalaman selanjutnya. Bagi Dewey, kesinambungan pengalaman yang menumbuhkan, tidak hanya secara fisik, tetapi juga secara intelektual dan moral, merupakan salah satu tolok ukur untuk menilai apakah suatu pengalaman bersifat mendidik atau tidak.

Misalnya, pengalaman di tingkat pendidikan dasar yang membuat subyek didik mengalami proses pembelajaran melulu sebagai beban berat yang harus ditanggung dan tidak ada kesenangan sedikitpun dalam belajar karena ia sendiri mengalami dan mendapatkan sesuatu yang bernilai, jelas tidak bersifat mendidik, karena pengalaman tersebut akan membuat kegiatan pembelajaran selanjutnya tidak dijalankan dengan sepenuh hati. Demikian juga, pengalaman yang mematikan rasa ingin tahu subyek didik, melemahkan inisiatifnya, dan banyak meredam keinginan dan cita-citanya.

Tolok ukur kedua yang diberikan oleh Dewey untuk menilai apakah pengalaman bersifat mendidik atau tidak adalah apakah pengalaman itu menjamin terjadinya interaksi antara realitas subyektif/internal dalam diri subjek didik dan realitas obyektif/eksternal yang menjadi kondisi nyata bagi subyek didik untuk hidup di tengah masyarakat dan zamannya. Pendidikan yang baik dan berbasiskan pengalaman memang perlu memperhatikan minat, bakat, keinginan, rasa ingin tahu, inisiatif dan kebebasan individu subyek didiknya sebagai realitas subyek/internal, tetapi tidak berarti lalu dapat mengabaikan tuntutan berdasarkan kondisi obyektif/eksternal yang menurut penilaian para pendidik sebagai orang dewasa layak diberikan. Berdasarkan pengalaman masa lalu yang terus diuji kembali dalam pengalaman sekarang, pengaturan sekolah, penentuan metode, pemilihan bahan, dan disiplin kerja yang mendukung pembelajaran subyek didik tetap dapat dan perlu dilakukan. Yang penting adalah jangan sampai hal-hal itu dilakukan tanpa memperhatikan kondisi subyek/internal subyek didik pada waktu dan tempat pembelajaran dilaksanakan. Menurut Dewey, pola pendidikan tradisional cenderung melupakan kondisi subyektif/internal subyek didik, sedangkan progresivisme cenderung melupakan kondisi obyektif/eksternal subjek didik. Akibatnya, pada keduanya pendidikan tidak dilakukan dengan sungguh-sungguh berbasis pengalaman subyek didik dalam konteks sosial-budaya atau kondisi obyektif masyarakatnya. 
Dengan pemahaman seperti itu, menurut Dewey (Glassman, 2001) peran pendidikan yang sangat penting adalah mengajar peserta didik tentang bagaimana menjalin hubungan antara sejumlah pengalaman sehingga terjadi penyimpulan dan pengujian pengetahuan baru. Pengalaman baru akan menjadi pengetahuan baru apabila seseorang selalu bertanya dalam hatinya. Jawaban terhadap pertanyaan tersebut merupakan pengetahuan baru yang tersimpan pada struktur kognitif seseorang. Pendapat Dewey menunjukkan bahwa pengetahuan baru akan terjadi bila ada pengalaman baru. Oleh karena itu, semakin banyak pengalaman belajar yang dialami seseorang akan semakin banyak pengetahuan yang dimilikinya.

Pengalaman baru peserta didik diperoleh dari sekolah, baik yang dirancang maupun tidak. Penentuan pengalaman yang diperoleh di sekolah harus melihat ke depan, yaitu tuntutan masyarakat di masa depan, karena perubahan yang dilakukan saat ini akan diperoleh hasilnya di masa depan. Akumulasi pengetahuan baru bagi peserta didik menentukan kemampuan peserta didik. Kemampuan ini sering disebut dengan kompetensi, yaitu kemampuan yang dapat dilakukan oleh peserta didik. Kompetensi ini sangat penting dalam era globalisasi, karena persaingan yang terjadi terletak pada kompetensi lulusan lembaga pendidikan atau pelatihan. Kompetensi lulusan ini ditentukan oleh pengalaman belajar peserta didik, sedang pengalaman belajar ini merupakan bagian dari kurikulum sekolah.

\section{b. Pandangan tentang peserta didik}

Bagi pragmatisme, subyek didik bukanlah pribadi yang pasif. Ia adalah manusia, makhluk hidup yang bertumbuh kembang dengan dan dalam interaksi secara aktif dengan lingkungan hidup di sekitarnya. Realitas bagi pragmatisme juga bukan suatu yang mati dan tak berubah, melainkan suatu yang dinamis dan terus berubah. Untuk itu, pendidikan mesti berpusat pada kondisi konkrit subyek didik dengan minat, bakat, dan kemampuannya serta peka terhadap perubahan yang terus terjadi dalam masyarakat. Pendidik haruslah senantiasa siap sedia untuk mengubah metode dan kebijakan perencanaan pembelajarannya, seiring dengan perkembangan zaman yang erat terkait dengan kemajuan sains dan teknologi serta perubahan lingkungan hidup tempat pembelajaran dilaksanakan

Dari sudut pandang epistemologi kaum pragmatis, siswa adalah seseorang yang mempunyai pengalaman (George R. Knight, 1982:66). Ia seorang individu berpengalaman yang mampu menggunakan kecerdasannya untuk memecahkan situasi-situasi problematik. Siswa belajar dari lingkungannya dan menjalani berbagai konsekuensi dari tindakan-tindakannya. Bagi kaum pragmatis, pengalaman sekolah adalah bagian dari hidup lebih daripada persiapan untuk hidup. Demikianlah, cara seseorang belajar di sekolah secara kualitatif tidak berbeda dari cara dia belajar dalam berbagai aspek lain kehidupannya. Sebagai siswa, setiap hari ia menghadapi berbagai masalah yang menyebabkannya mengalami pengalaman reflektif yang lengkap. Penggunaan yang dihasilkan oleh kecerdasannya menyebabkan tumbuh dan pertumbuhan ini memampukan dia untuk berinteraksi dengan dan beradaptasi terhadap dunia yang berubah. Ide yang berkembang menjadi alat untuk hidup yang sukses.

\section{c. Pandangannya tentang peran guru}

Guru menurut pragmatisme bukanlah guru dalam pengertian tradisionil. Yakni, ia bukan seseorang yang tahu apa yang dibutuhkan siswa di masa depan dan oleh karenanya mempunyai fungsi memberi/menanamkan seperangkat pengetahuan esensial kepada siswa. Untuk satu hal, 
kaum pragmatis mengaku, tak seorangpun tahu apa yang siswa butuhkan sejak ia hidup di dunia yang berubah secara terus-menerus. Fakta ini sejalan dengan idea bahwa tak ada satu kebenaran secara apriori atau mutlak yang mana semua siswa harus mengetahui memodifikasi peran guru.

Guru dalam sebuah sekolah yang pragmatik dapat dipandang sebagai anggota pelajar dalam pengalaman pendidikan karena masuk kelas setiap hari menghadapi dunia yang berubah. Namun, guru adalah anggota perjalanan yang lebih berpengalaman dan oleh karena itu dapat dipandang sebagai pembimbing atau direktur proyek. Dia adalah orang yang menasehati dan membimbing aktivitas-aktivitas siswa dan dia menampilkan peran ini di dalam konteks dan dengan keuntungan pengalaman yang lebih luas. Tetapi, yang penting untuk dicatat, dia tidak mendasarkan kegiatankegiatan kelas pada kebutuhan perasaannya sendiri.

\section{d. Pandangan tentang kurikulum}

Pragmatisme berkeyakinan mengenai perlunya menempatkan siswa, kebutuhan dan minatnya sebagai sesuatu yang sentral. Mata pelajaran, mereka claim, seharusnya dipilih dengan mengacu pada kebutuhan siswa. Selain itu, kurikulum seharusnya tidak dibagi ke dalam bidang matapelajaran yang bersifat membatasi dan tak wajar. Kurikulum mestinya lebih dibangun di seputar unit-unit yang wajar yang timbul dari pertanyaan-pertanyaan yang mendesak dan pengalaman-pengalaman siswa. Unit-unit studi yang spesifik mungkin bervariasi dari kelas 4 dan berikutnya, tapi ideanya adalah bahwa mata pelajaran sekolah yang tradisionil (seni, sejarah, matematika, membaca, dan lain-lain) dapat disusun ke dalam teknik problem solving yang berguna untuk menumbuhkan rasa ingin tahu siswa untuk belajar materi-materi tradisionil sebagaimana mereka bekerja pada problemproblem atau isu-isu yang telah menarik mereka di dalam pengalaman sehari-hari.

\section{e. Pandangan tentang metode pendidikan}

Menurut pragmatisme, metode pendidikan adalah upaya menanamkan suatu disiplin, tetapi bukan otoritas. Metode pengajaran dengan disiplin berarti seseorang mengarahkan pelajaran dengan disiplin. Cara yang dapat ditempuh adalah: (1) semua paksaan harus dibuang; guru harus membangkitkan "impulse" anak didik, sehingga timbul kekuatan internal untuk belajar mencapai "mastery" (ketuntasan). (2) Agar dapat muncul minat, guru harus intim dengan kecakapan dan minat setiap murid. Tidak ada minat universal, maka minat dan kemauan terhadap pelajaranpun berbeda-beda, (3) Guru harus menciptakan situasi di kelas sehingga setiap orang turut berpartisipasi dalam proses belajar.

Metode pendidikan seharusnya berpusat pada memberi siswa banyak kebebasan memilih dalam mencari-cari situasi-situasi belajar berpengalaman yang akan menjadi paling bermakna baginya. Kelas (yang dipandang tidak hanya sebagai setting sekolah, tetapi tempat dimana pengalaman diperoleh) dilihat di dalam hubungannya dengan sebuah laboratorium keilmuan dimana gagasan diletakkan untuk diuji dan dikritisi. Studi lapangan, dalam catatan kaum pragmatis, jelas memberi keuntungan-keuntungan lebih, karena memberi kesempatan berinteraksi langsung dengan lingkungan.

Adalah benar bahwa studi lapangan dan pengalaman aktual lainnya banyak menyita waktu. Namun, dengan metode itu mereka tampak lebih termotivasi. Sebagai contoh, seseorang belajar lebih tentang perusahaan susu dan sapi dengan langsung ke gudang dan pemerahan, membau dan mendengar suara seekor sapi daripada dengan seminggu membaca dan memandang proses pada layar film. Dengan demikian, metodologi pragmatisme adalah langsung dengan pengalaman mereka. 
Dengan kata lain, anak-anak, menurut Dewey, seharusnya secara bertahap berubah dari belajar berdasarkan pengalaman langsung ke metode belajar yang seolah mengalami sendiri/dialami orang lain. Metode ini seharusnya lebih bermakna karena mereka membangun berdasarkan basis pengetahuan yang ditemukan pada pengalaman-pengalaman signifikan dalam hidup sehari-hari. Dari segi kebijakan sosial sekolah, tujuan sekolah adalah bukan agar siswa mengingat serangkaian pengetahuan, tetapi lebih agar mereka belajar bagaimana belajar agar supaya mereka dapat menyesuaikan dengan dunia yang berubah secara terus menerus pada masa sekarang dan yang akan datang.

\section{f. Pandangannya mengenai demokrasi}

Sudut pandang politis dari pragmatisme adalah sudut pandang demokrasi. Pragmatisme melihat sekolah, secara ideal, sebagai sebuah kehidupan dan lingkungan belajar yang demokratis di mana setiap orang berpartisipasi dalam proses pembuatan keputusan, sebagai latihan dan persiapan untuk berpartisipasi dalam kehidupan masyarakat yang lebih besar. Keputusan masyarakat dan sekolah dalam kerangka ini dinilai dalam sudut pandang konsekuensi-konsekuensi sosialnya, tidak sekedar dengan parameter tradisi yang dikeramatkan. Perubahan sosial, ekonomi dan politik dipandang baik jika hal itu memperbaiki kondisi masyarakat.

Terkait dengan pandangan politik demokrasi tersebut, tokoh pragmatisme yang paling terkenal adalah John Dewey. Di antara karya John Dewey, ${ }^{12}$ Democracy and Education adalah buku yang memperlihatkan keyakinan-keyakinan dan wawasan-wawasannya tentang pendidikan serta mempraktekkannya di sekolah-sekolah yang ia dirikan. Karya ini berisi dasar-dasar pemikiran mengenai pendidikan, kehidupan sosial dan politik. Di dalam bukunya ini, John Dewey mengatakan bahwa demokrasi merupakan sesuatu yang lebih daripada suatu pengertian politik; demokrasi merupakan suatu kehidupan bersama yang saling berkaitan dan saling mengkomunikasikan pengalaman. John Dewey mengatakan, bahwa suatu masyarakat hanya akan ada karena suatu komunikasi, karena saling membagi pengetahuan, dan itulah kriteria etis suatu masyarakat yang baik.

Jadi, demokrasi dan pendidikan dilihat sebagai semacam dua muka dari suatu mata uang, demokrasi tidak dapat hidup tanpa pendidikan, dan sebaliknya pendidikan yang baik tidak akan hidup dalam suatu masyarakat yang tidak demokratis. Di dalam pemikirannya mengenai kaitan antara demokrasi dan pendidikan, Dewey beranggapan bahwa manusia perorangan hanya dapat terbentuk apabila dalam rangka kegunaan sosialnya. Namun demikian, pemikiran John Dewey ini tidak memassalkan individu, malahan menganggap bahwa setiap individu adalah unik, artinya yang tidak pernah lebur di dalam massa.

\section{d. Implikasi Pragmatisme Bagi Dunia Pendidikan di Indonesia}

Mencermati berbagai pandangan pragmatisme tentang pendidikan sebagaimana dikemukakan di atas, pertanyaannya adalah apakah berbagai pandangan tersebut sudah terwujud, dalam arti mewarnai praktek pendidikan di Indonesia? Bisa ditanyakan, misalnya, seberapa jauh praktek pendidikan di Indonesia dewasa ini menghormati prinsip-prinsip pendidikan berbasiskan pengalaman? Betulkah pendidikan di Indonesia berpusat pada subyek didik dan memperhatikan

\footnotetext{
${ }^{12}$ John Dewey adalah seorang filsof yang banyak menulis buku-buku dan artikel di bidang filsafat dan pendidikan. Hasil karyanya, antara lain: My Pedagogic Creed (1897); School and Society (1899); How we Think (1910); Democracy and Education (1916); Experience and Education (1938) dan Education Today (1940).
} 
baik kondisi subyektif/internal mereka maupun kondisi objektif dunia dan masyarakat kita dewasa ini? Dan, masih banyak lagi pertanyaan yang bisa diajukan.

\section{Menghormati prinsip pendidikan berbasiskan pengalaman}

Sebagaimana telah ditekankan, bahwa menurut pragmatisme (Glassman, 2001) peran pendidikan yang sangat penting adalah mengajar peserta didik tentang bagaimana menjalin hubungan antara sejumlah pengalaman sehingga terjadi penyimpulan dan pengujian pengetahuan baru. Pengalaman baru akan menjadi pengetahuan baru apabila seseorang selalu bertanya dalam hatinya. Jawaban terhadap pertanyaan tersebut merupakan pengetahuan baru yang tersimpan pada struktur kognitif seseorang. Pendapat tersebut menunjukkan bahwa pengetahuan baru akan terjadi bila ada pengalaman baru. Oleh karena itu, semakin banyak pengalaman belajar yang dialami seseorang akan semakin banyak pengetahuan yang dimilikinya.

Pengalaman baru peserta didik diperoleh dari sekolah, baik yang dirancang maupun tidak. Penentuan pengalaman yang diperoleh di sekolah harus melihat ke depan, yaitu tuntutan masyarakat di masa depan, karena perubahan yang dilakukan saat ini akan diperoleh hasilnya di masa depan. Selanjutnya, akumulasi pengetahuan baru bagi peserta didik menentukan kemampuan peserta didik. Kemampuan ini sering disebut dengan kompetensi, yaitu kemampuan yang dapat dilakukan oleh peserta didik. Kompetensi ini sangat penting dalam era globalisasi, karena persaingan yang terjadi terletak pada kompetensi lulusan lembaga pendidikan atau pelatihan. Kompetensi lulusan ini ditentukan oleh pengalaman belajar peserta didik, sedang pengalaman belajar ini merupakan bagian dari kurikulum sekolah.

Kini di Indonesia, berlaku Kurikulum Tingkat Satuan Pendidikan. Sama dengan kurikulum 2004 sebelumnya, yang sering disebut KBK, maka KTSP jelas sangat menekankan pentingnya keragaman pengalaman belajar peserta didik agar standar kompetensi dan kompetensi dasar bisa dicapai oleh peserta didik. Dalam rambu-rambu pelaksanaan kurikulum dan lampiran contohcontoh silabus, didalamnya memuat kolom pengalaman belajar peserta didik tersebut. Dalam glossary menyangkut istilah-istilah yang digunakan dalam KTSP tersebut istilah "pengalaman belajar " peserta didik menunjuk pada aktivitas belajar yang dilakukan siswa melalui interaksi siswa dengan obyek atau sumber belajar. Pengalaman belajar dapat dipilih sesuai dengan kompetensinya, dapat diperoleh di dalam kelas dan di luar kelas. Bentuknya dapat berupa kegiatan mendemonstrasikan, mempraktikkan, mensimulasikan, mengadakan eksperimen, menganalisis, mengaplikasikan, menemukan, mengamati, meneliti, menelaah, dan lain-lain, yang bukan kegiatan interaksi gurusiswa seperti mendengarkan uraian guru, berdiskusi di bawah bimbingan guru, dan lain-lain sejenisnya."

Jadi, secara formal jelas bahwa prinsip pendidikan berbasiskan pengalaman sebagaimana ditekankan dalam pragmatisme, diakui dan disarankan dipraktekkan dalam dunia pendidikan di Indonesia. Kurikulum tingkat satuan pendidikan yang berbasis pada kompetensi, jelas sangat menekankan pentingnya seorang guru menggunakan strategi dan media pembelajaran yang beragam $^{13}$, maksudnya antara lain agar peserta didik dapat melakukan berbagai variasi pengalaman belajar, sehingga kompetensi dasar yang ditetapkan bisa tercapai secara lebih efektif dan efisien. Sebagai satu contoh mengenai bagaimana keragaman pengalaman belajar tersebut sungguh-sungguh ditekankan dalam KTSP, agar Standar Kompetensi dan Kompetensi Dasarnya dapat dicapai oleh siswa, tercermin misalnya dalam buku yang diterbitkan oleh Penerbit Erlangga, 2007. Dalam buku

\footnotetext{
${ }^{13}$ Lihat rambu-rambu pelaksanaan kurikulum KTSP.
} 
Pendidikan Kewarganegaraan, khususnya pada topik "Peranan Pers dalam Kehidupan Masyarakat yang Demokratis", peserta didik diberi tugas atau "pengalaman belajar" tertentu, yang pada intinya dipakai untuk semakin mengasah penguasaan kompetensi peserta didik. Pada sub bab "Fungsi Pers dalam Masyarakat Demokratis", misalnya, mereka diminta mengerjakan tugas atau pengalaman belajar berikut.

Lakukan pengamatan terhadap seluruh isi sebuah media massa (cukup satu edisi penerbitan saja). Lalu, buatlah evaluasi sejauhmanakah media massa tersebut sudah menjalankan fungsinya sebagai media informasi, media pendidikan, media hiburan, dan media kontrol sosial! Manakah di antara keempat fungsi tersebut yang lebih dominan ditunjukkan oleh media massa tersebut?

Kemudian, peserta didik dengan dibantu media gambar juga diminta melakukan "refleksi terhadap pengalaman pribadi", dengan dipandu beberapa pertanyaan reflektif. Pada refleksi pengalaman pribadi, peserta didik diminta merefleksi pengalaman yang tercermin dari tiga gambar: (1) gambar 1: seseorang sedang membaca berita dalam surat kabar/majalah yang isinya cenderung berupa fitnah kepada seseorang, (2) gambar 2: seseorang sedang menonton siaran berita tentang konflik di televisi yang isinya ternyata cenderung memihak salah satu kelompok, dan (3) gambar 3: seseorang sedang mendengarkan siaran dialog interaktif di radio yang ternyata isinya cenderung seronok.

Peserta didik diminta memperhatikan gambar tersebut, lalu diminta menjawab pertanyaan berikut:

1. Manakah pengalaman dalam gambar tersebut yang pernah kalian alami? Atau, sebutkan pengalaman kalian yang mirip dengan gambar tersebut!

2. Bagaimana perasaan kalian ketika menyaksikan berita/siaran semacam itu?

3. Sadarkah kalian bahwa berita/siaran semacam itu termasuk "penyalahgunaan kebebasan pers"?

4. Bagaimanakah perasaan kalian apabila kalian berada dalam posisi sebagai korban dari berita/ siaran tersebut? Perlakuan seperti apa yang kalian harapkan?

5. Apa makna yang dapat kalian petik dari pengalaman tersebut?

Setelah peserta didik selesai menjawab pertanyaan tersebut, mereka diminta bergabung dalam kelompok terdiri dari 4 orang. Kemudian, masing-masing diminta untuk menceriterakan dan atau mendengarkan jawaban temannya dengan hati yang terbuka, lalu membuat laporan hasil dari kegiatan berbagi pengalaman dalam kelompok tersebut.

Demikianlah, contoh penerapan prinsip pendidikan berbasis pengalaman sebagaimana dikemukakan oleh John Dewey dalam konteks penerapan KTSP di Indonesia. Sekali lagi, secara formal prinsip tersebut sangat diakui dan disarankan untuk diterapkan, hanya dalam pelaksanaannya memang tergantung sekali pada guru, apakah guru mau melaksanakan atau tidak. Acapkali persoalannya terutama bukan apakah guru mampu, tapi lebih pada mau atau tidak melaksanakannya.

2. Pendidikan yang berpusat pada subyek didik

Pragmatisme mengidealkan anak sebagai subyek yang aktif, bukan pasif. Tentang hal inipun, kiranya telah disadari pentingnya di Indonesia, tetapi yang terjadi dalam praktek prinsip tersebut belum dilaksanakan secara optimal. H.A.R Tilaar (2006:19) malah menyatakan bahwa di Indonesia telah terjadi obyektivikasi anak. Katanya: 
...obyektivikasi anak Indonesia telah membawa proses pendidikan kepada proses reifikasi. Proses reifikasi pendidikan berarti membendakan segala sesuatu yang dijadikan sebagai obyek. Anak Indonesia sebagai obyek adalah sesuatu yang dapat diukur, yang dapat memenuhi tuntutan-tuntutan tertentu, yaitu kompetensi-kompetensi yang dapat diukur.

Menurut penulis, di Indonesia pada umumnya masih lebih menerapkan teacher centre strategies dan material centre strategies katimbang student centre strategies. Teacher centre strategies adalah strategi belajar mengajar yang berpusat pada guru. Dalam hal ini, mengajar adalah penyampaian informasi kepada peserta didik. Dalam pengertian yang demikian, maka tekanan pada strategi belajar mengajar terletak pada guru itu sendiri, di mana guru sebagai sumber informasi mempunyai posisi yang sangat dominan. Belajar dalam pendekatan ini adalah menerima informasi dari guru.

Sedangkan dalam material centre strategies, strategi belajar mengajar lebih berpusat pada materi. Belajar dengan demikian adalah usaha untuk menguasai informasi. Dalam strategi belajar mengajar yang demikian, menyebabkan (1) kecenderungan pada dominasi kognitif di mana pendidikan afektif dan ketrampilan kurang mendapatkan tempat yang seimbang dalam rangka peningkatan kualitas manusia Indonesia seutuhnya. Selain itu, materi pelajaran yang disampaikan di dalam kelas, dan yang di muat dalam buku teks, akan makin usang dengan pesatnya perkembangan ilmu pengetahuan dan teknologi. Materi pelajaran itu lebih berfungsi sebagai masukan (input) yang akan luluh dalam proses belajar mengajar.

Sekolah diciptakan untuk tempat para siswa belajar. Dengan pengertian ini, mestinya guru dan berbagai fasilitas pembelajaran yang lain disediakan untuk membantu siswa melaksanakan kegiatan belajarnya. Siswa menjadi pusat seluruh kegiatan belajar mengajar di sekolah (student centered). Dalam hal ini, mestinya peran guru di depan kelas lebih diposisikan sebagai motivator, mediator, fasilitator dan evaluator. Bila ada guru yang jauh lebih aktif mengajar dibandingkan siswanya di sekolah, perilaku tersebut jelas menyalahi dasar-dasar pembelajaran. Jadi, dalam hal ini guru memang diharapkan menjadi ujung tombak bagaimana prinsip student centered itu bisa diterapkan secara optimal, tentu dengan didukung oleh segenap komponen sistem pendidikan lainnya.

Pendidikan di Indonesia, juga belum memperhatikan secara optimal baik kondisi subyektif/ internal peserta didik maupun kondisi objektif dunia dan masyarakat kita. Pembelajaran mestinya adaptif, dalam arti memperhatikan latarbelakang, kecerdasan, gaya belajar peserta didik, di samping juga memperhatikan segala hal yang terjadi di dunia dan masyarakat yang berpengaruh terhadap pendidikan. Namun yang terjadi dalam pendidikan di Indonesia, pendidikan masih relatif sangat tradisionil, sangat klasikal, dan tidak dimulai dengan mengidentifikasi kondisi dan karakteristik peserta didik.

\section{KESIMPULAN}

Dari uraian di atas dapat disimpulkan hal-hal sebagai berikut,

1. Filsafat pragmatisme menyatakan bahwa benar tidaknya suatu teori bergantung pada berfaedah atau tidaknya teori itu bagi manusia dalam penghidupannya. Dengan demikian, ukuran untuk segala perbuatan adalah manfaatnya dalam praktek dan hasil yang memajukan hidup.

2. Lahirnya pragmatisme dilatarbelakangi oleh kritiknya terhadap filsafat-filsafat tradisional yang bersifat statis dan cenderung melihat segala sesuatu sebagaimana adanya. Menurut para tokoh pragmatisme, filsafat tradisionil yang ada belum mampu memberikan jawaban yang memuaskan 
terhadap kehidupan manusia, sehingga mereka menawarkan sesuatu yang praktis bagi kehidupan manusia, yang beorientasi pada asas efisiensi dan manfaat.

3. Kaitan sekaligus pengaruh filsafat pragmatisme terhadap humanisme pendidikan modern terwujud melalui pengaruh teori pendidikan progresivisme. Pragmatisme juga mempengaruhi pendidikan baik secara langsung maupun tidak, melalui rekonstruksionisme, futurisme, dan deschooling dalam pendidikan.

4. Dalam filsafat pragmatisme, pengalaman adalah basis pendidikan. Pendidikan merupakan suatu proses penggalian dan pengolahan pengalaman secara terus-menerus. Inti pendidikan adalah usaha untuk terus-menerus menyusun kembali (reconstruction) dan menata ulang (reorganization) pengalaman hidup subjek didik. Pendidikan haruslah memampukan subjek didik untuk menafsirkan dan memaknai rangkaian pengalamannya sedemikian rupa, sehingga ia terus bertumbuh dan diperkaya oleh pengalaman tersebut.

5. Hakekat pendidikan semacam itu, berimplikasi pada segenap komponen pendidikan lainnya, dalam pandangannya tentang peserta didik, peran guru, kurikulum, metode pendidikan dan lain lain. Intinya, bahwa segenap komponen pendidikan lainnya kondusif atau mendukung terwujudnya ideal pendidikan yang menempatkan pengalaman sebagai basis orientasinya.

6. Pendidikan berbasis pengalaman sangat diakui dan disarankan secara formal di Indonesia. Ketentuan-ketentuan yang dimuat dalam kurikulum kita, sangat menekankan agar pendidikan dan pembelajaran memberi pengalaman yang beragam pada peserta didik.

7. Menghormati prinsip pendidikan berbasis pengalaman, berpusat pada peserta didik, dan memperhatikan secara optimal baik kondisi subyektif/internal peserta didik maupun kondisi objektif, adalah beberapa implikasi dari filsafat pragmatisme.

\section{DAFTAR PUSTAKA}

Albertine Minderop. 2005. Pragmatisme Amerika. Jakarta: Obor.

Barnadib, Imam. 1994. Hand Out Filsafat Pendidikan, Progdi Ilmu Filsafat PPS UGM, Yogyakarta. 2002. Filsafat Pendidikan. Yogyakarta: Adi Cita.

Bertens. 1998. Ringkasan Sejarah Filsafat. Yogyakarta: Penerbit Kanisius.

Douglas J. Simpson. 2005. John Dewey and the Art of Teaching. London: Sage Publications.

Driyarkara. 2007. Karya Lengkap Driyarkara. Jakarta: PT. Gramedia.

F. Budi Hardiman. 2007. Filsafat Modern. Jakarta: PT Gramedia.

George F. Kneller. 1966. Foundations of Education. New York: John Wiley and Sons, Inc.

George R. Knight.1982. Issues and Alternatives in educational Philosophy. Michigan: Andrews University Press.

Glassman, M. 2001. Dewey and Vygotsky: Society, experience, and inquiry in educational practice. Educational Researcher, Vol.30, No. 4, pp.3-14.

John Dewey. 2004. Experience and Education. Bandung: Teraju (terjemahan)

. 1956. Philosophy of Education. Iowa: Littlefield, Adams Co.

1958. Experience and Nature. New York: Dover Publications, INC. 
Muis Sad Iman. 2004. Pendidikan Partisipatif. Yogyakarta. Safiria Insania Press.

Paulo Freire. 2001. Menggugat Pendidikan. Yogyakarta: Pustaka pelajar.

Tilaar, H.A.R. 1999. Pendidikan, Kebudayaan, dan Masyarakat Madani Indonesia, Penerbit PT Remaja Rosdakarya, Bandung. 2005. Manifesto Pendidikan Nasional. Tinjauan dari Perspektif Postmodernisme dan Studi Kultural. Jakarta: Kompas. 
Satya Widya, Vol. 28, No.2. Desember 2012 